\title{
Effect of Relative Plate Thickness in the Heat Flow and Cooling Rate during Welding of Super Duplex Stainless Steel
}

André de Albuquerque Vicente ${ }^{1,2 *}$, Roberto Luiz de Souza ${ }^{2}$, Denise Crocce Romano Espinosa ${ }^{2}$, Renato Rodrigues de Aguiar $^{2}$, Pexcin Paul ${ }^{3}$, Amilton Barbosa Botelho Junior ${ }^{1}$

${ }^{1}$ Department of Chemical Engineering, Universidade de São Paulo, Rua do Lago, 250, Cidade Universitária, São Paulo, SP, Brazil

${ }^{2}$ ESAB Middle East \& Africa, Plot No. S20134, Jebel Ali Free Zone (South), PO Box 8964, Dubai, United Arab Emirates

${ }^{3}$ Penta Global Engineering Company LLC, Plot No. 47NR27, ICAD III, PO BOX 8276, Mussafah, Abu Dhabi, United Arab Emirates

\author{
DOI: $\underline{10.36348 / \text { sjet.2020.v05i05.005 }}$ \\ | Received: 19.05.2020 | Accepted: 27.05.2020 | Published: 30.05.2020
}

*Corresponding author: André de Albuquerque Vicente

\section{Abstract}

Duplex stainless steels are characterized by their biphasic, ferritic-austenitic microstructure. The ideal volumetric fraction of these phases in duplex stainless steels, is of 50\% ferrite and 50\% austenite, however, this condition is difficult to be obtained when arc welding these materials. A detailed analysis of the effect of relative plate thickness in the heat flow and, consequently, in the cooling rate during welding of duplex stainless steel is of fundamental importance. The correct adjustment of the welding parameters leads to an optimum cooling rate of the joint, which guarantees a good balance of the volume fractions of ferrite and austenite, and results in acceptable mechanical properties and corrosion resistance. In this work, the best welding practices to the duplex stainless steel UNS S32750 (Super Duplex) were studied, guaranteeing welded joints that showed the ideal volumetric fractions of ferrite and austenite and, consequently, the mechanical properties according to the project. Complementary techniques of microstructural analysis were used, such as optical emission spectrometry, optical microscopy and quantitative image analysis.

Keywords: Duplex Stainless Steels; PREN; Volume Fraction.

Copyright @ 2020: This is an open-access article distributed under the terms of the Creative Commons Attribution license which permits unrestricted use, distribution, and reproduction in any medium for non-commercial use (NonCommercial, or CC-BY-NC) provided the original author and source are credited.

\section{INTRODUCTION}

Duplex stainless steels (DSS) are steels that present biphasic microstructure containing ferrite and austenite in volumetric fractions approximately equal to $50 \%$.

Due to their biphasic microstructure, these steels present a favorable combination of the properties of ferritic and austenitic stainless steels [1].

Depending on the cooling speed and the maintenance time in certain temperature ranges, precipitation of other phases may occur, in addition to ferrite and austenite, leading to the weakening of these steels. The embrittlement of duplex stainless steels can be divided into two groups: embrittlement of low temperature and embrittlement of high temperature. Low-temperature embrittlement usually occurs in a temperature range of $300^{\circ} \mathrm{C}$ to $500^{\circ} \mathrm{C}$, where precipitation of the alpha' ( $\left.\alpha^{\prime}\right)$ phase, called $475^{\circ} \mathrm{C}$ embrittlement, occurs. It is usually associated with the use of the equipment in service and, therefore, limits the maximum application temperature of duplex stainless steels below $280^{\circ} \mathrm{C}$. High temperature embrittlement occurs in the temperature range from $600^{\circ} \mathrm{C}$ to $1000^{\circ} \mathrm{C}$, where several intermetallic phases precipitate, such as the sigma $(\sigma)$, chi $(\chi)$, carbides $\left(\mathrm{M}_{23} \mathrm{C}_{6}\right)$ and chrome nitrides $\left(\mathrm{Cr}_{2} \mathrm{~N}\right)$ phases. This type of embrittlement can occur during welding or post-welding heat treatment. The main phases that can precipitate and significantly influence the properties of duplex and super duplex stainless steels are carbides of the $\mathrm{M}_{23} \mathrm{C}_{6}$ type, the sigma phase $(\sigma)$, the alpha ' $\left(\alpha^{\prime}\right)$ phase and the chrome nitrides, among others. The sigma phase $(\sigma)$ is an intermetallic phase with a tetragonal lattice, extremely hard, non-magnetic, and causes embrittlement when precipitated in the material. The sigma phase $(\sigma)$ begins precipitation at the ferrite-austenite interfaces and its main constituents are chromium and molybdenum. The precipitation of sigma phase $(\sigma)$, impoverishes the ferritic matrix in its grain contours, removing the elements chromium and molybdenum which are precisely the agents that promote corrosion resistance [1-9]. 
$\mathrm{M}_{23} \mathrm{C}_{6}$ carbides usually appear in duplex stainless steels with a high chromium content. The alpha' $(\alpha$ ') phase (secondary ferrite) normally occurs between $300^{\circ} \mathrm{C}$ and $550^{\circ} \mathrm{C}$. Intermetallic precipitations can be initiated from temperatures of approximately $570^{\circ} \mathrm{C}$, with an intensification in the range of $800^{\circ} \mathrm{C}$ to $850^{\circ} \mathrm{C}[1-9]$.
Figure-1 shows a typical TTT curve of a super duplex stainless steel highlighting the effect of the major alloying elements on the precipitation of deleterious phases.

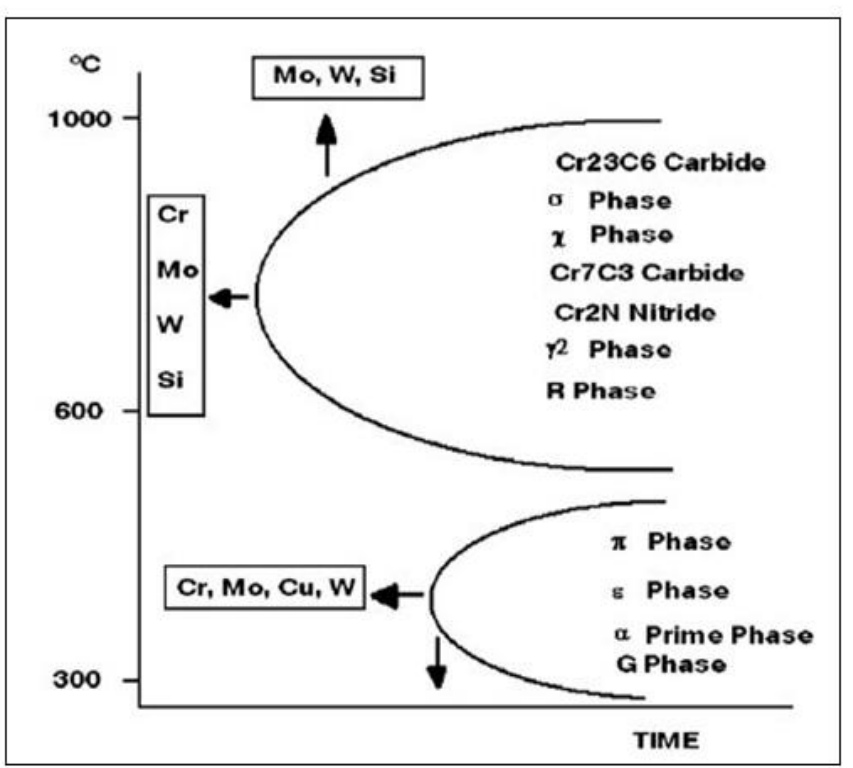

Fig-1: Typical TTT curve of a super duplex steel highlighting the effect of some alloying elements on the precipitation of deleterious phases [2]

In order to obtain joints with biphasic microstructure and volumetric fractions of the ferrite and austenite phases close to $50 \%$, the cooling speed of the welded joint must be controlled.

Figure-2 presents, in a very didactic way, the results obtained in a welded joint submitted to different cooling speeds. It is observed that the very fast cooling leads to the precipitation of chromium nitrides of the $\mathrm{Cr}_{2} \mathrm{~N}$ type due to the volumetric fraction of ferrite being very high (blue cooling rate). On the other hand, very slow cooling leads to the precipitation of harmful phases. Sigma phase $(\sigma)$ precipitation is observed (red cooling rate).

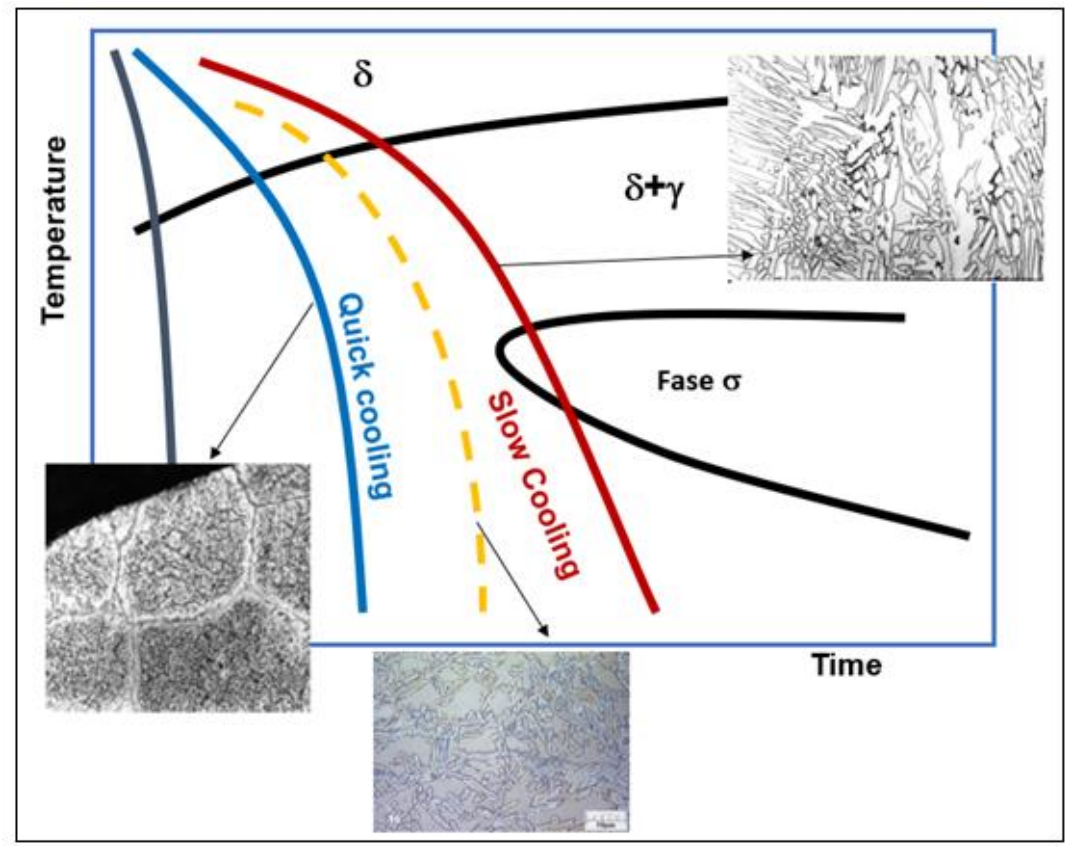

Fig-2: Continuous cooling transformation curve (CCT) of duplex stainless steel UNS S32750 (Super Duplex), highlighting the effects of the different cooling rates on the precipitations of deleterious phase 
An adequate parameterization of the welding process leads to an optimum cooling speed of the welded joint, obtaining volumetric fractions of ferrite and austenite close to $50 \%$ and avoiding the precipitation of deleterious phases (yellow cooling rate).

The thermal conditions in and near welds govern the resulting metallurgical structure, mechanical properties, residual stress and distortion of the welded part [10].

Different features of the weldment are of particular significance, as follows:

- Weld bead area;

- Peak temperatures in the Heat Affected Zone (HAZ);

- $\quad$ Cooling rates in the weld and HAZ;

- Width of HAZ and;

- Weld solidification rate $[10,11]$.

Thickness of the plate to be welded directly governs cooling rate of a specific location. Accordingly, two different empirical equations are used for

The cooling rate $(\mathrm{R})$ equations are presented below:

Thin plates: $\left(2 \pi k \rho C(h / H n e t)(T i-T o)^{3}\right)$

Thick plates: $\left(2 \pi k(\mathrm{Ti}-\mathrm{T} 0)^{2}\right) / \mathrm{Hnet}^{\circ} \mathrm{C} / \mathrm{s}$

Where $\mathrm{h}$ is the plate thickness $(\mathrm{mm}), \mathrm{k}$ is thermal conductivity, $\rho$ is the density $\left(\mathrm{g} / \mathrm{cm}^{3}\right), \mathrm{C}$ is specific heat $\left(\mathrm{kCal} /{ }^{\circ} \mathrm{C} . \mathrm{g}\right)$, $\mathrm{Ti}$ is the temperature of interest $\left({ }^{\circ} \mathrm{C}\right)$, and To is the initial plate temperature $\left({ }^{\circ} \mathrm{C}\right)$ $[10,11]$.

\section{EXPERIMENTAL}

Three samples tubes from the same heat of duplex stainless steels UNS S32750 (Super Duplex) with thickness of $2.77 \mathrm{~mm}$ were used.

The samples were welded through GTAW process. The welding wire used was the ER2594 2.4 $\mathrm{mm}$. The shielding gas used was $98 \% \mathrm{Ar}+2 \% \mathrm{Ni}$ and the purge gas used was $99.99 \%$ Ar.

The specimens were removed from the base metal and the joints of the tubes using a cut-off. Chemical analyzes were carried out in all samples by means of an optical emission spectrometer, according to ASTM E 1086-08 [12].

Afterwards, the samples were embedded in hot-cure resin (bakelite). The conventional manual polishing was applied using water slicks $(100,240,320$, 400, 600 and 1000 mesh) in order to standardize the calculating the cooling rate in HAZ depending upon the relative plate thickness and welding conditions [10,11].

The relative plate thickness criteria considers all the relevant factors which can affect the cooling rate such as thickness of the plate (h), heat input (Hnet), initial plate temperature (To), temperature of interest at which cooling rate is desired (Ti) and physical properties of plate like (specific heat $C$, density $\rho$ ). Relative plate thickness $(\tau)$ can be calculated using following equation:

$$
\tau=h(\rho C(T i-\text { To }) / \text { Hnet })^{1 / 2}
$$

(Equation 1) [10]

Thin plate cooling rate equation is used when relative plate thickness $\tau<0.6$ and thick plate cooling rate equation is used when $\tau>0.9[10,11]$.

If value of $\tau$ is in range of 0.6 to 0.9 , then 0.75 is used as a limit value to decide the cooling rate equation to be used $[10,11]$.

Cooling rate equations can be used to calculate the critical cooling rate (CCR) under a given set of welding conditions and to determine the preheat temperature requirement for the plate in order to avoid the CCR $[10,11]$.

(Equation 2) [10]

(Equation 3) [10]

surface finish of the samples. Afterwards, a cloth polishing with 9,3 and $1 \mu \mathrm{m}$ diamond abrasive paste was carried out in this sequence. The samples were electrolytically attacked in $20 \% \mathrm{NaOH}$ solution, $6 \mathrm{~V}$, for 90 seconds. This allowed the microstructural characterization of the samples through optical microscopy. The quantitative metallographic analyzes for the determination of volumetric fractions of $\delta$ ferrite and austenite were performed according to ASTM E 562 ed. 08 [13], using a 4 X 5 grid (20 points) with a magnification of $400 \mathrm{X}$ in 30 different regions per test piece.

Finally, tensile tests were performed on welded joints to evaluate their mechanical properties. The preparation of the sub-size specimens to the tensile test was according to ASTM E8/E8M-16ae1 [14].

\section{RESULTS AND DISCUSSION}

The calculation of the relative plate thickness was done using Equation 1, and the welding parameters used. As shown in Table-1, all the samples presented values of the relative plate thickness smaller than 0.6. In this way, the calculation of the cooling rates where done using Equation 2, for thin plates. 
André de Albuquerque Vicente et al., Saudi J Eng Technol, May, 2020; 5(5): 244-250

Table-1: Welding parameters and respective calculated results for heat input, relative plate thickness, cooling rate and time needed to chill out the joints from $1510{ }^{\circ} \mathrm{C}$ to $850{ }^{\circ} \mathrm{C}$

\begin{tabular}{|l|l|l|l|l|l|l|l|l|}
\hline & Welding Parameters & Thers & & & & \\
\hline & Tension (V) & Current (A) & $\begin{array}{l}\text { Travel } \\
\text { Speed } \\
(\mathbf{m m} / \mathbf{s})\end{array}$ & $\begin{array}{l}\text { Thermal } \\
\text { Efficiency } \\
(\%)\end{array}$ & $\begin{array}{l}\text { Heat } \\
\text { Input } \\
(\mathbf{k J} / \mathbf{m m})\end{array}$ & $\begin{array}{l}\text { Relative } \\
\text { Plate } \\
\text { Thickness }\end{array}$ & $\begin{array}{l}\text { Cooling } \\
\text { Rate } \\
\left({ }^{\circ} \mathbf{C} / \mathbf{s}\right)\end{array}$ & $\begin{array}{l}\text { Time } \\
\mathbf{1 5 1 0 - 8 5 0} \\
{ }^{\circ} \mathbf{C}(\mathbf{s})\end{array}$ \\
\hline Sample 1 & 9.5 & 52.0 & 1.00 & 80 & 0.40 & 0.27 & 20.37 & 32.41 \\
\hline Sample 2 & 10.0 & 54.0 & 0.38 & 80 & 1.14 & 0.16 & 2.46 & 268.17 \\
\hline Sample 3 & 12.0 & 55.0 & 0.30 & 80 & 1.76 & 0.13 & 1.03 & 642.73 \\
\hline
\end{tabular}

In order to calculate the relative plate thickness and consequently the cooling rates of the joints, the physical properties used were as shown in Table-2.

Table-2: Physical properties of the duplex stainless steel UNS S32750 (Super Duplex)

\begin{tabular}{|l|l|}
\hline $\mathbf{h}$ & $2.77 \mathrm{~mm}$ \\
\hline To & $25^{\circ} \mathrm{C}$ \\
\hline Tc & $850^{\circ} \mathrm{C}$ \\
\hline pC & $0.0047 \mathrm{~J} / \mathrm{mm}^{3}{ }^{\circ} \mathrm{C}$ \\
\hline $\mathbf{k}$ & $0.025 \mathrm{~W} / \mathrm{mm}^{\circ} \mathrm{C}$ \\
\hline
\end{tabular}

It is important to emphasize that the critical temperature was defined as $850{ }^{\circ} \mathrm{C}$, according to the TTT Diagram of the super duplex stainless steel UNS32750, as shown in Figure 3. According to the
TTT Diagram, $850{ }^{\circ} \mathrm{C}$ would be the temperature for which sigma phase $(\sigma)$ precipitates in less then $0.1 \mathrm{~h}$ hour of exposure.

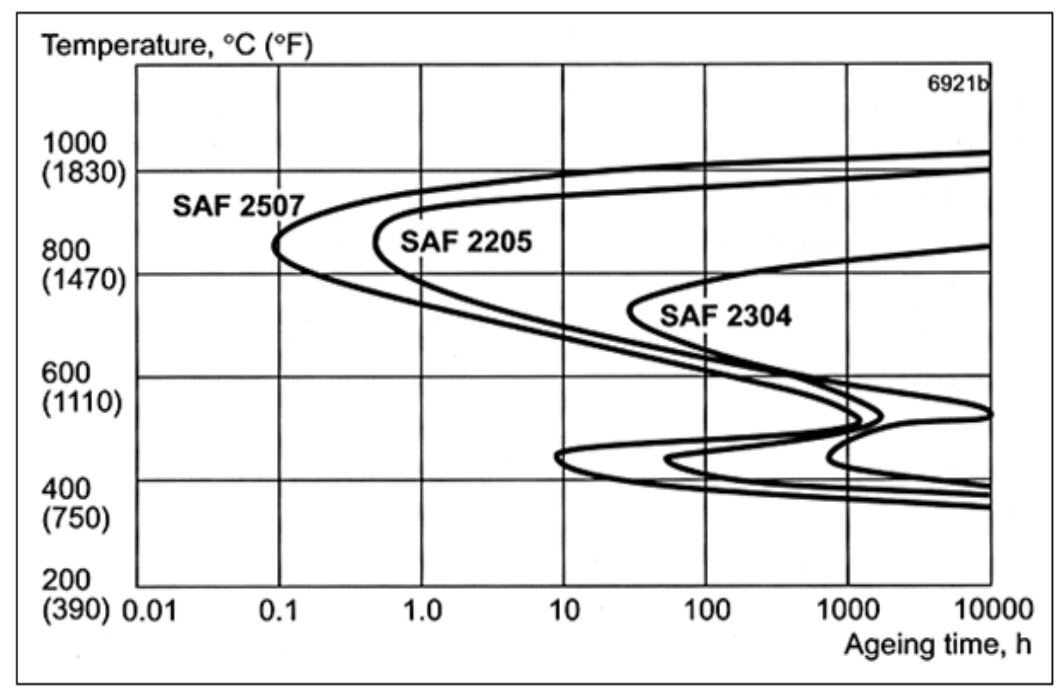

Fig-3: Time Temperature Transformation (TTT) diagram of duplex stainless steel UNS S32750 [15]

Table-3 presents the chemical compositions, as well as the PRENs of the base metal UNS S32750, the filler metal ER2594 and the three welded joints prepared with different welding parameters.

Table-3: Chemical compositions of the studied stainless steels ( $\%$ by weight).

\begin{tabular}{|l|c|c|c|c|c|c|c|c|c|c|c|}
\hline & \% C & \%Si & \%Mn & \%P & \%S & \% Cr & \%Ni & \%Mo & \% Cu & \%N & PREN \\
\hline UNS S32750 & 0,013 & 0,43 & 0,64 & 0,024 & 0,000 & 24,91 & 6,97 & 3,76 & 0,08 & 0,28 & 41,80 \\
\hline ER 2594 & 0,010 & 0,38 & 0,48 & 0,021 & 0,001 & 25,14 & 9,50 & 3,92 & 0,09 & 0,24 & 41,92 \\
\hline Sample 1 & 0,010 & 0,39 & 0,50 & 0,021 & 0,001 & 25,12 & 9,25 & 3,90 & 0,09 & 0,24 & 41,90 \\
\hline Sample 2 & 0,010 & 0,39 & 0,50 & 0,021 & 0,001 & 25,11 & 9,12 & 3,90 & 0,09 & 0,25 & 41,90 \\
\hline Sample 3 & 0,011 & 0,39 & 0,51 & 0,022 & 0,001 & 25,09 & 8,99 & 3,89 & 0,09 & 0,25 & 41,89 \\
\hline
\end{tabular}

Figure-4 shows the micrographs of the base metal and the three welded joints. The typical microstructures of laminated and welded duplex stainless steels is observed, where the dark phase is $\delta$ ferrite and the clear phase austenite. 

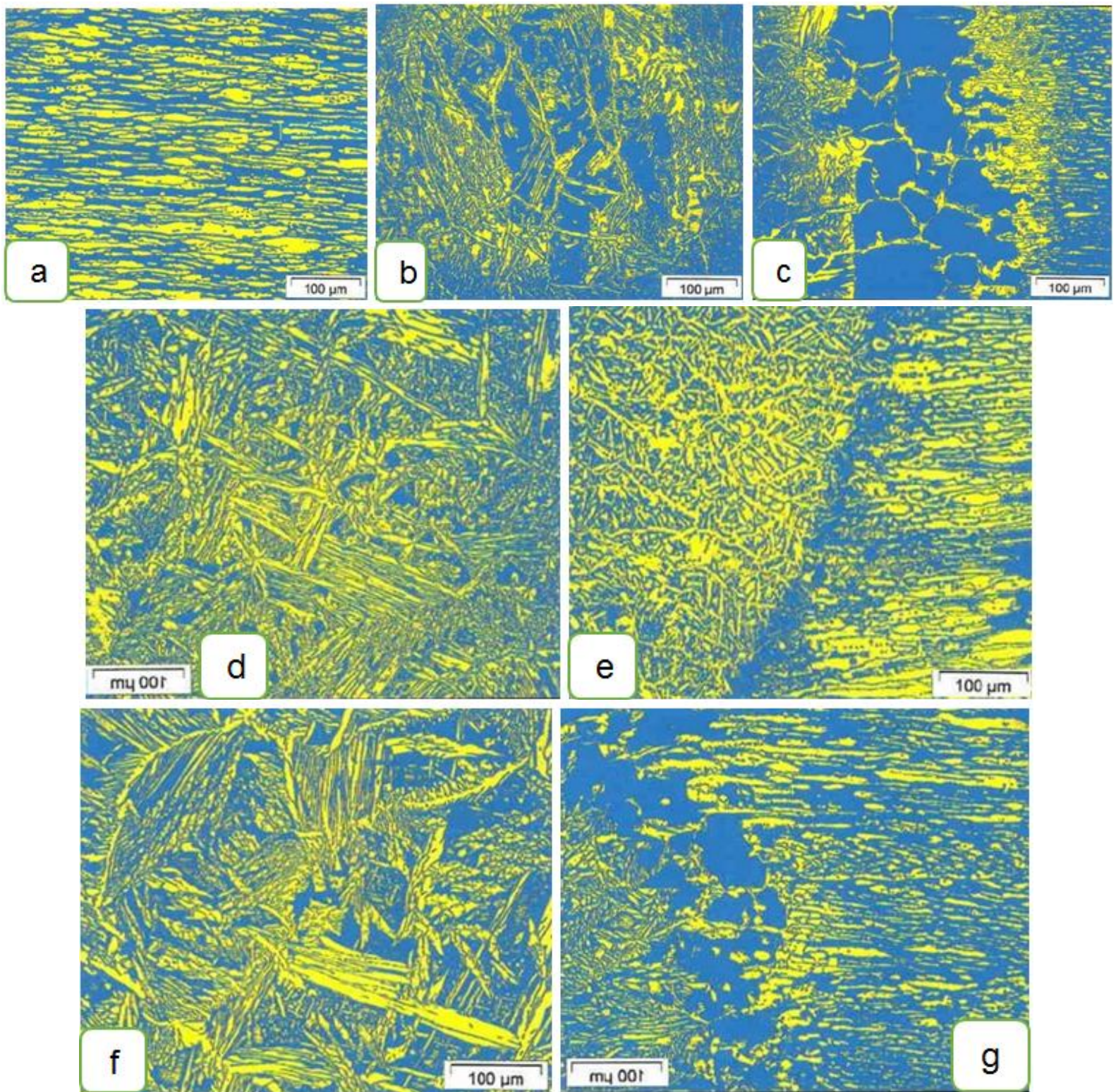

Fig-4: Micrographs of the base metal and the welded joints: a) UNS S32750, b) Sample 1 (all weld metal), c) Sample 1 (heat affected zone), d). Sample 2 (all weld metal), e) Sample 2 (heat affected zone), f) Sample 3 (all weld metal) and g) Sample 3 (heat affected zone)

Table-4 presents the volumetric fractions of $\delta$ ferrite and austenite obtained by measurements in 30 different regions per test specimen according to the micrographs shown in Figure-4.

Table-4: Volumetric fractions of $\delta$ ferrite and austenite

\begin{tabular}{|l|l|l|l|}
\hline & \% $\delta$ Ferrite & 95\% CI & \% RA \\
\hline UNS S32750 & 51.33 & 2.45 & 4.12 \\
\hline Sample 1 (all weld metal) & 63.28 & 4.12 & 6.94, \\
\hline Sample 1 (heat affected zone) & 69.72 & 4.16 & 7.14 \\
\hline Sample 2 (all weld metal) & 51,78 & 2,12 & 3,82 \\
\hline Sample 2 (heat affected zone) & 52.08 & 1,88 & 3,78 \\
\hline Sample 3 (all weld metal) & 54,13 & 2.88 & 4,13 \\
\hline Sample 3 (heat affected zone) & 58.17 & 3.75 & 5.12 \\
\hline
\end{tabular}

Analyzing the macrographs from Figure-4, and the volumetric fractions of $\delta$ ferrite and austenite from Table 4, sample 1 presented the highest volume fraction of $\delta$ ferrite both in the all weld metal and in the heat affected zone. This fact may be directly related to the highest cooling rate calculated on Table-1, of 20.37 ${ }^{\circ} \mathrm{C} / \mathrm{s}$.

The duplex stainless steels solidify according to ferritic-austenitic solidification $(\mathrm{L} \rightarrow \mathrm{L}+\delta \rightarrow \mathrm{L}+\delta+\gamma \rightarrow \delta+\gamma)$. 
The solubility limit of nitrogen in $\delta$ ferrite at $592{ }^{\circ} \mathrm{C}$ is of $0.10 \%$ in weight, while in austenite at $650{ }^{\circ} \mathrm{C}$ is $2.80 \%$ in weight [2].

As discussed before, if the cooling rate is high, there is not enough time to the formation of austenite phase, and it leads to the precipitation of chromium nitrides of the $\mathrm{Cr}_{2} \mathrm{~N}$ type.

Sample 3 was exposed to a cooling rate of 1.03 ${ }^{\circ} \mathrm{C} / \mathrm{s}$. According to the calculation of the time needed to this joint chill from $1510{ }^{\circ} \mathrm{C}$ to $850{ }^{\circ} \mathrm{C}$ out, shown on Table-1, in 642 seconds the cooling rate will cross the field of beginning of formation of sigma phase $(\sigma)$.

The sigma phase $(\sigma)$ begins precipitation at the ferrite-austenite interfaces and its main constituents are chromium and molybdenum. The precipitation of sigma phase $(\sigma)$, impoverishes the ferritic matrix in its grain contours, removing the elements chromium and molybdenum which are precisely the agents that promote corrosion resistance [4].

At Figure-5, in a more detailed micrograph of sample 3, some precipitation of intermetallic phases could be observed.

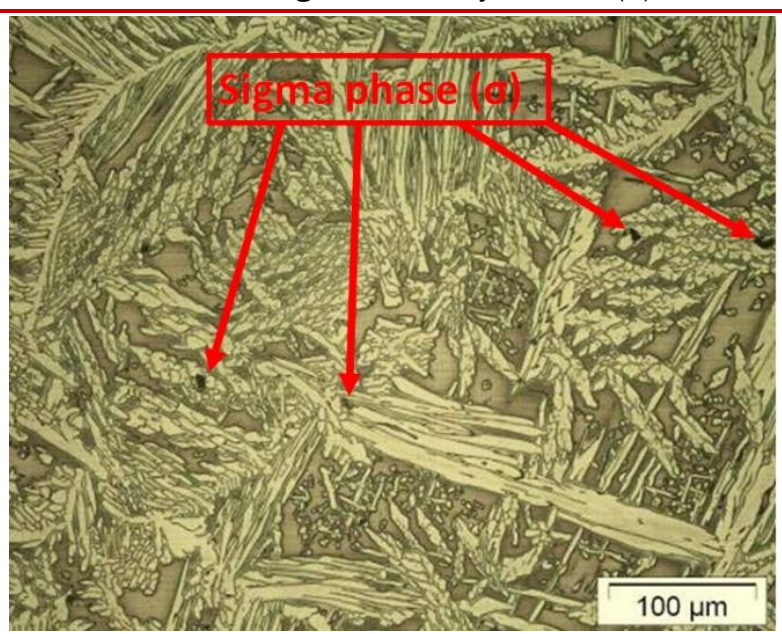

Fig-5: Micrograph of the all weld metal of Sample 3 showing precipitation of intermetallic phases

Sample 2 showed the best results of the volumetric fractions of $\delta$ ferrite and austenite, suggesting that welding parameters led to an optimum cooling rate of the join.

Table-5 presents the results of the tensile tests and the respective volume fractions of $\delta$ ferrite in the $\mathrm{HAZ}$ of the joints studied.

Table-5: Mechanical properties and volumetric fractions of $\delta$ ferrite

\begin{tabular}{|l|l|l|l|l|}
\hline & Yield Strength (Mpa) & Tensile Strength (Mpa) & Elongation (\%) & \% $\delta$ Ferrite \\
\hline UNS S32750 & 687 & 975 & 29 & 51 \\
\hline Sample 1 & 538 & 752 & 12 & 69 \\
\hline Sample 2 & 671 & 935 & 27 & 52 \\
\hline Sample 3 & 680 & 888 & 20 & 58 \\
\hline
\end{tabular}

It is observed in Table-5 that the volume fraction of $\delta$ ferrite phase presents direct correlation with the mechanical properties of the duplex stainless steels.

As expected, sample 2 presented the best mechanical properties when compared to the other samples studied. These results reinforce that a detailed analysis of the effect of relative plate thickness in the heat flow and, consequently, in the cooling rate during welding of duplex stainless steel is of fundamental importance.

The correct adjustment of the welding parameters leads to an optimum cooling rate of the joint, which guarantees a good balance of the volume fractions of $\delta$ ferrite and austenite, and results in acceptable mechanical properties and corrosion resistance.

\section{CONCLUSIONS}

Depending on the thickness of the base metal, the detailed adjustment of heat input can guarantee that the joint chills out at the optimum cooling rate.
Low heat input can lead to a high cooling rate of the welded joint, resulting in lower volume fraction of austenite and, consequently, reduction of elongation in the joint.

High heat input can lead to a low cooling rate of the welded joint, resulting in precipitation of intermetallic phases such as the sigma $(\sigma)$ and chi $(\chi)$ phases and carbides $\left(\mathrm{M}_{23} \mathrm{C}_{6}\right)$.

In order to obtain joints with biphasic microstructure and volumetric fractions of the $\delta$ ferrite and austenite phases close to $50 \%$, the cooling rate of the welded joint must be projected through a detailed study of the joint and the physical properties of the base metal.

\section{REFERENCES}

1. Vicente, A. D. A. (2017). Estudo da resistência à oxidação ao ar a altas temperaturas de um aço inoxidável austenítico microligado ao cério soldado pelo processo mig/mag com diferentes gases de proteção (Doctoral dissertation, Universidade de São Paulo). 
André de Albuquerque Vicente et al., Saudi J Eng Technol, May, 2020; 5(5): 244-250

2. de Albuquerque Vicente, A., dos Santos, I. L., Junior, A. B. B., Crocce, D., Espinosa, R., \& Tenório, J. A. S. (2020). Study of the Distribution of $\mathrm{Cr}, \mathrm{Mo}, \mathrm{Ni}$ and $\mathrm{N}$ in $\delta$ Ferrite and Austenite in Duplex Stainless Steels. Saudi Journal of Engineering and Technology, 5(4), 156-162.

3. Santa-Cruz, L. A., Machado, G., Vicente, A. A., Hermenegildo, T. F. C., \& Santos, T. F. A. (2019). Effect of high anodic polarization on the passive layer properties of superduplex stainless steel friction stir welds at different chloride electrolyte $\mathrm{pH}$ values and temperatures. International Journal of Minerals, Metallurgy, and Materials, 26(6), 710-721.

4. Marques, I. J., Vicente, A. D. A., Tenório, J. A. S., \& Santos, T. F. D. A. (2017). Double kinetics of intermetallic phase precipitation in UNS S32205 duplex stainless steels submitted to isothermal heat treatment. Materials Research, 20, 152-158.

5. Vicente, A. D. A., Cabral, D. A., Espinosa, D. C. R., \& Tenório, J. A. S. (2018). Efeito dos gases de proteção na microestrutura e nas cinéticas de oxidação a altas temperaturas ao ar de juntas soldadas de um aço inoxidável austenítico através do processo mig/mag. Tecnologia em Metalurgia, Materiais e Mineração, 14(4), 357-365.

6. Marques, I. J., Silva, F. J., \& Santos, T. F. (2020). Rapid precipitation of intermetallic phases during isothermal treatment of duplex stainless steel joints produced by friction stir welding. Journal of Alloys and Compounds, 820, 153170.

7. Santos, T. F. A., Torres, E. A., Lippold, J. C., \& Ramirez, A. J. (2016). Detailed microstructural characterization and restoration mechanisms of duplex and superduplex stainless steel friction-stirwelded joints. Journal of Materials Engineering and Performance, 25(12), 5173-5188.

8. Santos, T. F. D. A., López, E. A. T., Fonseca, E. B. D., \& Ramirez, A. J. (2016). Friction stir welding of duplex and superduplex stainless steels and some aspects of microstructural characterization and mechanical performance. Materials Research, 19(1), 117-131.

9. Santa Cruz, L. A., Marques, I. J., Urtiga Filho, S. L., Hermenegildo, T. F., \& Santos, T. F. (2019). Corrosion Evaluation of Duplex and Superduplex Stainless Steel Friction Stir Welds Using Potentiodynamic Measurements and Immersion Tests in Chloride Environments. Metallography, Microstructure, and Analysis, 8(1), 32-44.

10. Sindo K. (2003). "Welding metallurgy", John Wiley \& Sons, Inc., USA. ISBN: 9780471434023.

11. Castro, J. A. D., Oliveira, E. M., Almeida, D. S. D. S., Fonseca, G. S. D., \& Xavier, C. R. (2017). Effects of Local Heat Input Conditions on the Thermophysical Properties of Super Duplex Stainless Steels (SDSS). Materials Research, 20, 153-161.

12. ASTM E1086-08: Standard Test Method for Optical Emission Vacuum Spectrometric Analysis of Stainless Steel by the Point-to-Plane Excitation Technique. ASTM International. West Conshohocken. PA. EUA. 2008.

13. ASTM E562-08: Standard Test Method for Determining Volume Fraction by Systematic Manual Point Count. ASTM International. West Conshohocken. PA. EUA. 2008.

14. ASTM E8/E8M-16ae1: Standard Test Methods for Tension Testing of Metallic Materials. ASTM International. West Conshohocken. PA. EUA. 2016.

15. Vicente, A. A. (2011). Welding Practice for the Sandvik Duplex Stainless Steels for the Sandvik Duplex Stainless Steels SAF 2304, SAF 2205 and SAF 2507. In: IIW European-South American School of Welding and Correlated Processes Study-group Welding Research Strategy and Collaboration. Ouro Preto. MG. Brazil. 